\title{
Three transisthmian snapping shrimps (Crustacea: Decapoda: Alpheidae: Alpheus) associated with innkeeper worms (Echiura: Thalassematidae) in Panama
}

\author{
ARTHUR ANKER ${ }^{1,5}$, CARLA HURT $^{1,3} \&$ NANCY KNOWLTON ${ }^{1,2,4}$ \\ IInstituto Smithsonian de Investigaciones Tropicales, Apartado 0843-03092, Balboa, Ancón, Panamá, República de Panamá / Smith- \\ sonian Tropical Research Institute, Naos Unit 0948, APO AA 34002, USA \\ ${ }^{2}$ Center for Marine Biodiversity and Conservation-0202, Scripps Institution of Oceanography, University of California San Diego, La \\ Jolla, CA, 92093-0202, USA \\ ${ }^{3}$ Present address: University of Miami, Department of Biology, Coral Gables, FL, 33124-9118, USA \\ ${ }^{4}$ Present address: National Museum of Natural History, Smithsonian Institution, Washington D. C., 20013-7012, USA \\ ${ }^{5}$ Corresponding author. E-mail: ankera@si.edu
}

\begin{abstract}
The present study deals with three species of Alpheus, including two new species, living symbiotically in burrows of innkeeper worms (Echiura: Thalassematidae) on the tropical coasts of the western Atlantic and eastern Pacific Oceans. Alpheus christofferseni $\mathbf{n}$. sp. is described on the basis of four specimens from Atol das Rocas, northwestern Brazil, and one specimen from Bocas del Toro, Caribbean coast of Panama. All specimens of this species were collected with suction pumps from burrows on intertidal or shallow subtidal sandflats; the Panamanian specimen was collected together with its echiuran host, Ochetostoma cf. edax (Fisher, 1946). Alpheus naos n. sp. is described on the basis of a single specimen found together with its host, Listriolobus sp., under large intertidal mud-covered rocks of Punta Culebra, Isla Naos, Pacific coast of Panama. Finally, two specimens of Alpheus aequus Kim \& Abele, 1988 were collected together with their hosts, Ochetostoma edax, in the mixed rock-sand-mud intertidal of Coiba, Pacific coast of Panama. Remarkably, these three species are nearly identical in morphology and are also similar in color patterns. However, despite their morphological and ecological similarities, they are among the most genetically distinct of transisthmian alpheid geminate taxa examined to date. Genetic analyses suggest that $A$. aequus and A. naos n. sp. form an eastern Pacific clade whose sister taxon is the slightly more distantly related western Atlantic A. christofferseni $\mathbf{n}$. sp. Estimated divergence times are 10 mya for the two eastern Pacific species, and 11-12 mya for the western Atlantic and eastern Pacific clades. Within Alpheus, A. christofferseni n. sp., A. aequus and A. naos n. sp. belong to the pantropical A. barbatus Coutière, 1897 species complex (A. barbatus clade), which also includes the eastern Atlantic A. ribeiroae Anker \& Dworschak, 2004 and the Indo-West Pacific A. barbatus. The association of all three American species with thalassematid echiurans, as well as previous reports of associations between $A$. barbatus and echiurans in the western Pacific, suggest that this symbiosis is relatively ancient, having evolved in the ancestor of the $A$. barbatus clade (at least 12 mya and probably earlier).
\end{abstract}

Key words: Alpheus, Alpheidae, snapping shrimp, Echiura, new species, infaunal, symbiosis, western Atlantic, eastern Pacific, transisthmian taxa, cryptic species, barcode, COI

\section{Introduction}

The snapping shrimp genus Alpheus Fabricus, 1798 presently includes over 300 species worldwide (e.g., Chace, 1972, 1988; Banner \& Banner, 1982; Kim \& Abele, 1988). To facilitate taxonomic work, this huge genus is currently subdivided into seven species groups (for definition of groups see Banner \& Banner, 1982); however, some of them are clearly not monophyletic (Williams et al., 2001; Anker, 2001a; Anker et al., 
2006). The large but relatively homogenous Alpheus brevirostris (Olivier, 1811) species group contains over 30 described species (Bruce, 1994), although the actual number of species is probably much higher due to the presence of numerous cryptic species, especially among the goby-associated members of this group (Bruce, 1994; Anker, 2000; Nomura, 2003). The A. brevirostris group also includes the small Alpheus barbatus Coutière, 1897 species complex, with three described species: the Indo-West Pacific A. barbatus; the eastern Pacifc A. aequus Kim \& Abele, 1988; and the eastern Atlantic A. ribeiroae Anker \& Dworschak, 2004. These species differ from the other species of the A. brevirostris group by having a very short rostrum, the major chela being short and stout, and having a deep oblique notch on the dorsal margin of the palm, the minor cheliped fingers with dense setal brushes (except in A. ribeiroae), and the uropods bearing two projecting acute teeth on the protopod and a distinctly bilobed diaeresis on the exopod (cf. Banner \& Banner, 1982; Kim \& Abele, 1988; Anker \& Dworschak, 2004).

Until now, the A. barbatus complex was not known to have representatives in the western Atlantic. However, in 2000, an extensive collection of marine invertebrates with a bait suction pump by F. B. Pitombo and R. Barroso (Museu Nacional, Rio de Janeiro, Brazil) at Atol das Rocas, off northwestern Brazil, yielded four complete specimens of an infaunal Alpheus species from the A. barbatus species complex. Through the courtesy of the late Dr. Paolo Young, we were able to examine these specimens and found that they belong to an undescribed species, most closely related to the eastern Pacific A. aequus. In October 2005, we obtained a single complete specimen of an infaunal Alpheus from a burrow of an innkeeper worm (Echiura) while sampling with a bait suction pump on a shallow seagrass flat in Bocas del Toro, Caribbean coast of Panama. We found only a few insignificant differences between this specimen and the previously examined specimens from Atol das Rocas, suggesting that they all belong to the same species. In March 2006, a single specimen of a species mophologically similar to $A$. aequus was collected by hand from the burrow of an echiuran near the extreme low tide mark in the mixed rock-mud intertidal of Punta Culebra, Isla Naos, in the vicinity of Panama City. In March 2007, two specimens of A. aequus were collected from echiuran tunnels at Coibita, a small island within the Coiba Marine National Park, $300 \mathrm{~km}$ west of Panama City. The Punta Culebra specimen was then compared to Coibita specimens that matched the description of A. aequus by Kim \& Abele (1988), and was found to represent another undescribed species. The two undescribed species are herewith described and illustrated; additional illustrations of $A$. aequus are also provided. Color patterns are illustrated for all three species. Finally, mitochondrial cytochrome oxidase I (COI) sequences as barcode identifiers and estimators of divergence time are provided for each species.

\section{Material and methods}

The Brazilian specimens were collected from burrows with the aid of bait suction pumps. The Bocas del Toro specimen was collected with a 30" Alvey steel bait suction ("yabby") pump, together with its host. The Punta Culebra and Coibita specimens were collected by hand, together with their hosts. All Panamanian specimens and their hosts were photographed alive prior to preservation. Small chunks of muscular tissue were taken from one of the ethanol-preserved paratypes of the new species from Atol das Rocas, as well as from the ethanol-preserved specimen from Bocas del Toro, for DNA sequencing. In the new species from Punta Culebra and in A. aequus, two legs were separated at the coxal basis immediately after photography and preserved in RNAlater (Ambion), while specimens themselves were preserved in $90 \%$ ethanol. The echiuran hosts were preserved in ethanol; a small piece was cut out of the proboscis for future DNA analysis. All drawings were made with the aid of a camera lucida under a dissecting microscope.

The type specimens of the new species are deposited in the collections of the Museu Nacional, Rio de Janeiro, Brazil (MNRJ). Non-type specimens are deposited in the collections of the National Museum of Natural History, Smithsonian Institution, Washington D.C., USA (USNM) and the Muséum national d'Histoire naturelle, Paris, France (MNHN). 
Abbreviations used in the text: Mxp - maxilliped; $\mathrm{P}$ - pereiopod; $\mathrm{CL}$ - carapace length (measured in $\mathrm{mm}$ along mid-dorsal line from the tip of the rostrum to the posterior margin of the carapace); TL - total length (measured in $\mathrm{mm}$ along mid-dorsal line from the tip of the rostrum to the posterior margin of the telson); fen field collection number.

COI sequences were obtained from cDNA rather than from direct amplification of genomic DNA, in order to reduce the risk of amplification of nuclear pseudogenes, previously shown to be pervasive within the genus Alpheus (Williams \& Knowlton, 2001). Total RNA was extracted using the SV Total RNA Isolation System (Promega) following manufacturers' instructions. First-strand synthesis of cDNA was performed using MuLV reverse transcriptase and RNase inhibitor (Applied Biosystems) and a $\mathrm{T}_{18}$ Reverse Primer. The resulting cDNA was then used as template in polymerase chain reaction (PCR) using universal primers HCOI/LCOI from Folmer et al. (1994) to amplify $665 \mathrm{bp}$ from the 5' end of the mitochondrial COI gene (corresponding to the target region for the COI Barcode) [www.barcodinglife.org], and primers COIF / COI(10) (Williams \& Knowlton, 2001) to amplify the adjacent 677 bp from the same gene, for a total of 1224 bp (sequences overlapped slightly).

PCR amplifications were carried out in 30- $\mu \mathrm{L}$ volumes containing $0.1 \mu \mathrm{M}$ forward and reverse primer, $200 \mu \mathrm{M}$ each dNTP, $2.0 \mathrm{mM} \mathrm{MgCl}{ }^{2+}, 1.5$ units of Amplitaq Gold DNA polymerase, and $3 \mu \mathrm{L}$ Amplitaq 10X PCR Buffer II. Thermocycler parameters were as follows: $95^{\circ} \mathrm{C}$ for $10 \mathrm{~min} ; 30$ cycles of $95^{\circ} \mathrm{C}$ for $30 \mathrm{~s}, 50^{\circ} \mathrm{C}$ for $30 \mathrm{~s}, 72^{\circ} \mathrm{C}$ for $1 \mathrm{~min}+2 \mathrm{~s} / \mathrm{cycle}$; with a $10 \mathrm{~min}$ final extension at $72^{\circ} \mathrm{C}$. PCR products were gel excised on a $1 \%(\mathrm{w} / \mathrm{v})$ low-melt agarose gel and extracted using the Wizard SV Gel and PCR Clean-UP System (Promega), following manufacturers' instructions. An aliquot $(2 \mu 1)$ of the purified PCR product was quantified by electrophoresis on an analytical gel, and DNA concentrations were determined by comparison of fluorescence with a standard DNA mass ladder. Cycle sequencing reactions were performed using 50-100ng DNA and BigDye terminator v3.1 (Applied Biosystems) following manufacturers' instructions for cycle sequencing. Reaction products were separated from unincorporated dye-terminators by centrifugation through Sephadex G-50 columns in a 96-well filter plate (Millipore). Products of sequencing reactions were run on a 3700 Applied Biosystems automated capillary sequencer.

Genetic distances were calculated using the Kimura-2-Parameter (K2P) distance method as implemented in Mega v3.1 in order to facilitate comparisons with alpheid distances obtained previously (Knowlton et al., 1993; Knowlton \& Weigt, 1998). A rate of $1.5 \%$ sequence divergence per million years was used to estimate the timing of divergence of sister taxa. This rate was estimated by averaging the K2P genetic distances for both 5' and 3' COI sequences obtained from the transisthmian sister species pair Alpheus antepaenultimus Kim \& Abele, 1988 / A. chacei Carvacho, 1979 (GenBank accession numbers AF309875, AF309876, AF309884, AF308989, AF308983, EF532616 - EF532619 ). This geminate species pair has the smallest observed genetic distance of all transisthmian comparisons, and its divergence is likely to correspond to the final closing of the Panamanian isthmus approximately three million years ago (Knowlton \& Weigt, 1998). This rate differs slightly from the published rate of 1.4\% (Knowlton \& Weigt, 1998), obtained from comparisons of COI sequences from the 3' end only.

\section{Taxonomy}

Alpheus Fabricius, 1798

Alpheus christofferseni n. sp.

Figs. 1-6, 11a-c, 12b, c

Material examined. Holotype: male (CL 6.8, TL 20.1), MNRJ 17905, Brazil, Atol das Rocas, Ilha do Cemitério, coll. F. B. Pitombo and R. Barroso, 24 Dec 2000. Paratypes: 1 female (CL 7.0, TL 22.9), MNRJ 
20048, same collection data as holotype; 2 females (CL 6.2, TL 17.5 and CL 6.2, TL 16.9, latter dissected), MNRJ 17926, Brazil, Atol das Rocas, in front of Ilha do Cemitério, near algal crest, with suction pump, coll. F. B Pitombo and R. Barroso, 31 Dec 2000.

Additional material examined. 1 male (CL 6.7, TL 19.7), USNM 1100667, Panama, Caribbean coast, Bocas del Toro, Isla Carenero, near Bucaneer resort, $15 \mathrm{~m}$ from shore, depth $0.5 \mathrm{~m}$, fine sand flat with seagrass, with suction pump, from burrow of Ochetostoma cf. edax (host collected and preserved), coll. A. Anker, 17 Oct 2005 [fen 05-019].

Description. Carapace smooth, not setose, laterally not compressed. Rostrum short, triangular to subtriangular, distally subacute (Fig. 1a, h), situated somewhat below dorsal-most portion of orbital hoods (Fig. 1b); mediorostral carina feebly marked, blunt and short, not reaching beyond eye level, posteriorly flattening (Fig. 1a); orbitorostral grooves very shallow; orbitorostral process not conspicuous. Orbital hoods moderately inflated, rounded, unarmed (Fig. 1a). Pterygostomial angle rounded, not protruding (Fig. 1b). Branchiostegial margin furnished with scarce setae. Cardiac notch relatively small. Eyes completely concealed in dorsal, lateral and partly frontal view. Ocellar beak well-developed, protruding vertically towards rostrum, visible in lateral view (Fig. 1b). Epistomial sclerite without acute projecting tooth.

Antennular peduncles moderately stout, second segment slightly longer than dorsally visible portion of first segment, about 1.5 times as long as wide (Fig. 1a); stylocerite short, distally blunt to subacute (Fig. 1a, b), not reaching distal margin of first segment; mesioventral carina of first segment with tooth as illustrated (Fig. 1c); lateral flagellum without independent secondary ramus, groups of aesthetasc tufts present starting from fifth segment (Fig. 1a, b). Antenna with basicerite lacking ventrolateral tooth (Fig. 1a, b); carpocerite robust, reaching distinctly beyond distal margin of antennular peduncle and scaphocerite; scaphocerite exceeding distal margin of antennular peduncle, with deep cleft between distolateral tooth and blade (Fig. 1a, d), lateral margin slightly concave (Fig. 1d), distolateral tooth reaching beyond anterior margin of blade (Fig. 1a, d).

Mouthparts (mandible, maxillule, maxilla, first and second maxillipeds) typical for Alpheus. Third maxilliped relatively stout (Fig. 1e); coxa with lateral plate ear-shaped, distally acute, furnished with long setae; antepenultimate segment flattened, with ventral margin somewhat rugose, dorsal margin with short, blunt distal projection; ultimate segment very setose; exopod not reaching penultimate segment; arthrobranch welldeveloped (Fig. 1e).

Major cheliped (Figs. 2a-c; 5a, b) with short, robust ischium; merus stout, about twice as long as wide, dorsal margin distally blunt, not projecting, ventromesial margin finely toothed, distally with subacute tooth (Fig. 2a, b); carpus cup-shaped, without distinct distal lobes; chela ovate, laterally compressed, subrectangular in cross-section; dorsal margin of palm with deep transverse notch subdistally (Fig. 2a, b), forming a broadly U-shaped groove in dorsal view; mesial face of palm smooth except for small depression near dorsal notch (Fig. 2a); lateral face with narrow, longitudinal dorsal depression extending from dorsal notch to linea impressa, and broad, very shallow ventral depression extending from base of pollex to about mid-length of palm (Fig. 2b); fingers about 3/5 length of palm; dactylus with short, distally truncate plunger, latter with stamen-shaped sensillae (Figs. 2b, 5c); adhesive discs rather small (Fig. 2b).

Female minor cheliped (Fig. 2d, e) with robust merus, about 2.5 times as long as wide; dorsal margin distally unarmed; ventromesial margin finely toothed, distally with small subacute tooth (Fig. 2d, e); carpus short, cup-shaped, with dorsomesial distal lobe; chela with palm about $3 / 5$ as long as fingers, without sculpture, ventral margin slightly concave, distomesial margin with prominent tooth (Fig. 2d, e); fingers relatively long, slender, gaping, laterally and mesially with rows of stiff setae along cutting edges, tips crossing. Male minor cheliped similar to female minor cheliped, but with fingers slightly longer and more robust (Figs. 2f, $5 \mathrm{~d}, \mathrm{e})$.

Second pereiopod relatively slender; ischium slightly longer than merus; carpus with five articles, with ratios (from proximal to distal) of approximately $5: 3: 1.5: 1.5: 2$ (Fig. 3a, h); chela simple, with fingers subequal to palm; palm as long as distal carpal article. Third and fourth pereiopods similar in shape, length and 

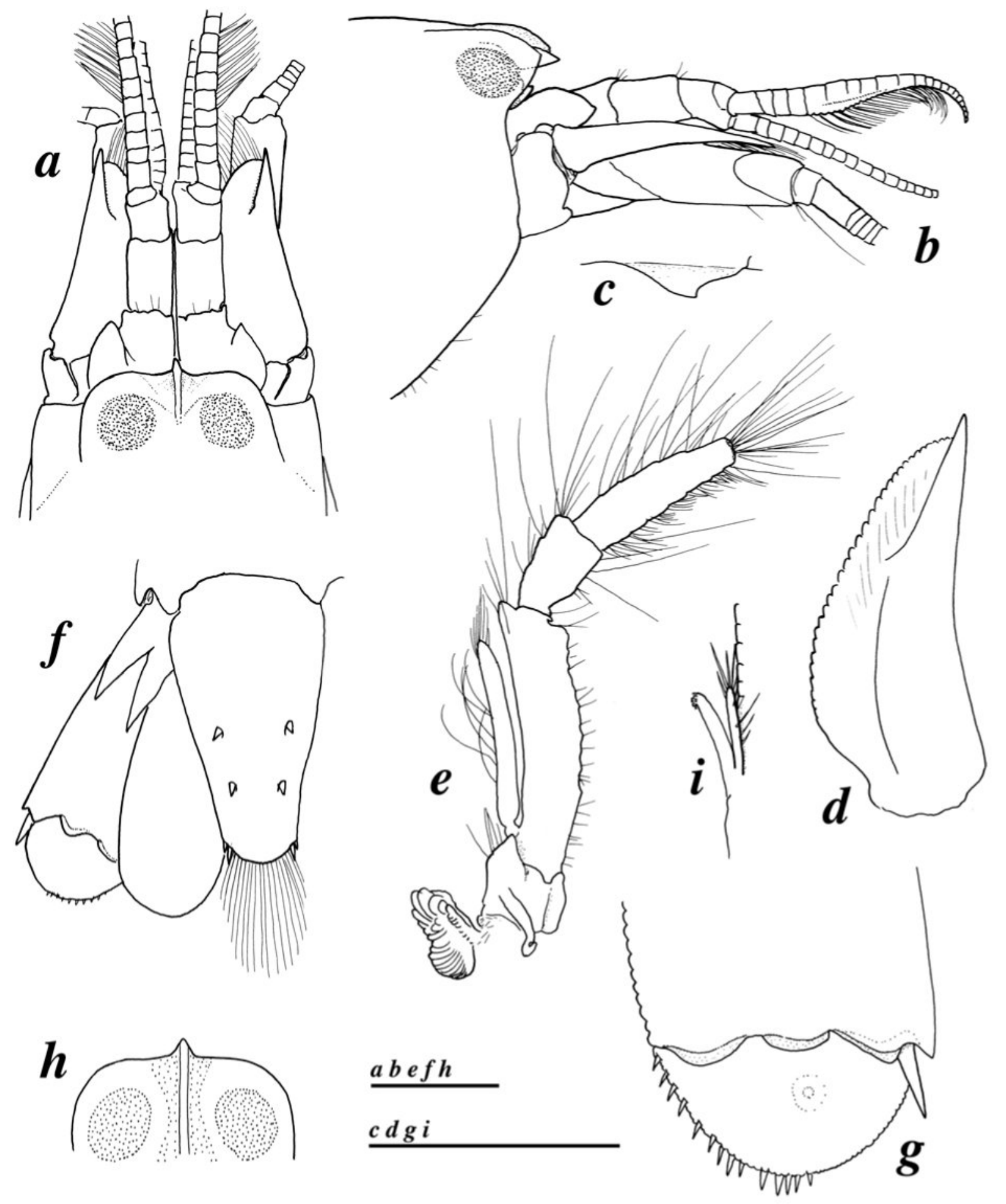

FIGURE 1. Alpheus christofferseni n. sp., female paratypes from Atol das Rocas, Brazil (MNRJ 17926) (a-h) and male holotype (MNRJ 17905) (i): a, frontal region, dorsal view; b, same, lateral view; c, tooth on mesioventral carina of first antennular segment, lateral view; d, scaphocerite of antenna, dorsal view; e, third maxilliped, lateral view; f, telson and left uropod, dorsal view; g, distal margin of exopod of right uropod; h, orbital hoods and rostrum of another specimen, dorsal view; i, appendix masculina and appendix interna of male second pleopod. Scale bars: $1 \mathrm{~mm}$. 

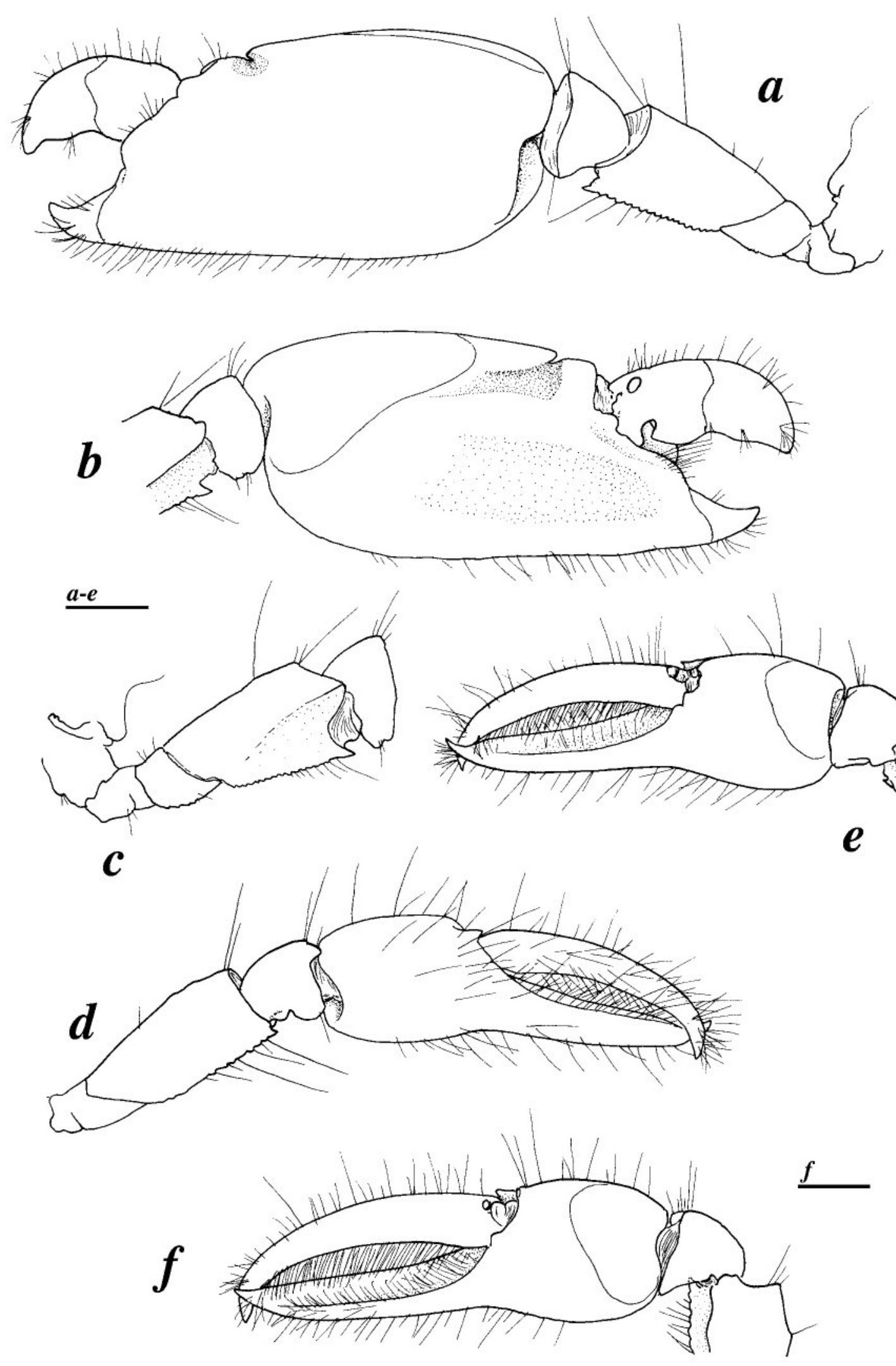

FIGURE 2. Alpheus christofferseni n. sp., female paratype from Atol das Rocas, Brazil (MNRJ 17926) (a-e) and male holotype (MNRJ 17905) (f): a, female major cheliped, mesial view; b, same, distal merus, carpus and chela, lateral view; c, same, coxa to carpus, lateral view; d, female minor cheliped, mesial view; e, same, distal merus, carpus and chela, lateral view; $\mathrm{f}$, male minor cheliped, distal merus, carpus and chela, lateral view. Scale bars: $1 \mathrm{~mm}$. 


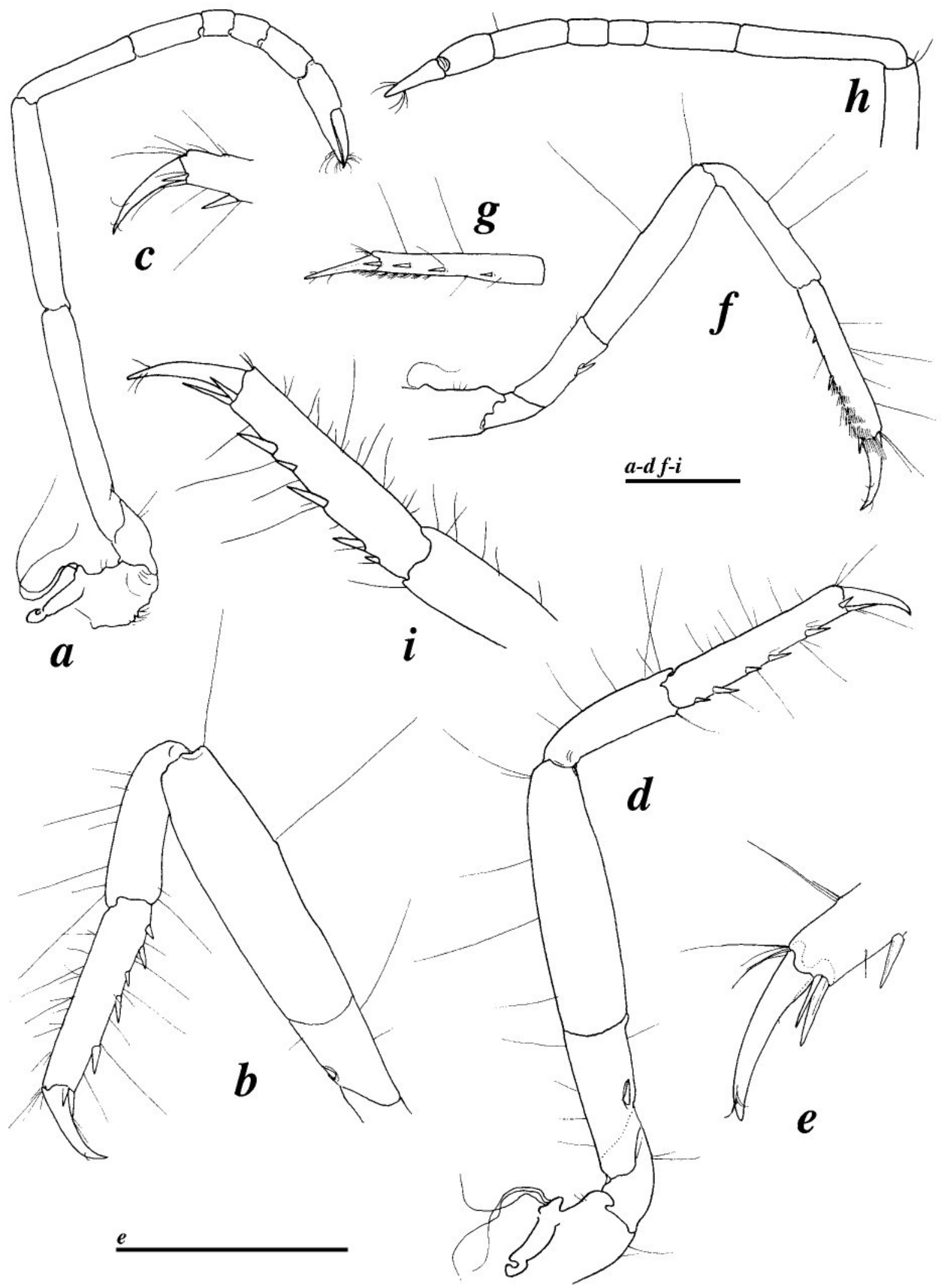

FIGURE 3. Alpheus christofferseni n. sp., female paratypes from Atol das Rocas, Brazil (MNRJ 17926): a, second pereiopod, lateral view; b, third pereiopod, lateral view; c, same, distal propodus and dactylus; $d$, fourth pereiopod, lateral view; e, same, distal propodus and dactylus; $\mathrm{f}$, fifth pereiopod, lateral view; g, same, propodus and dactylus, ventral view; $\mathrm{h}$, second pereiopod of another specimen, carpus and chela; i, third pereiopod of another specimen, distal carpus, propodus and dactylus, lateral view. Scale bars: $1 \mathrm{~mm}$. 


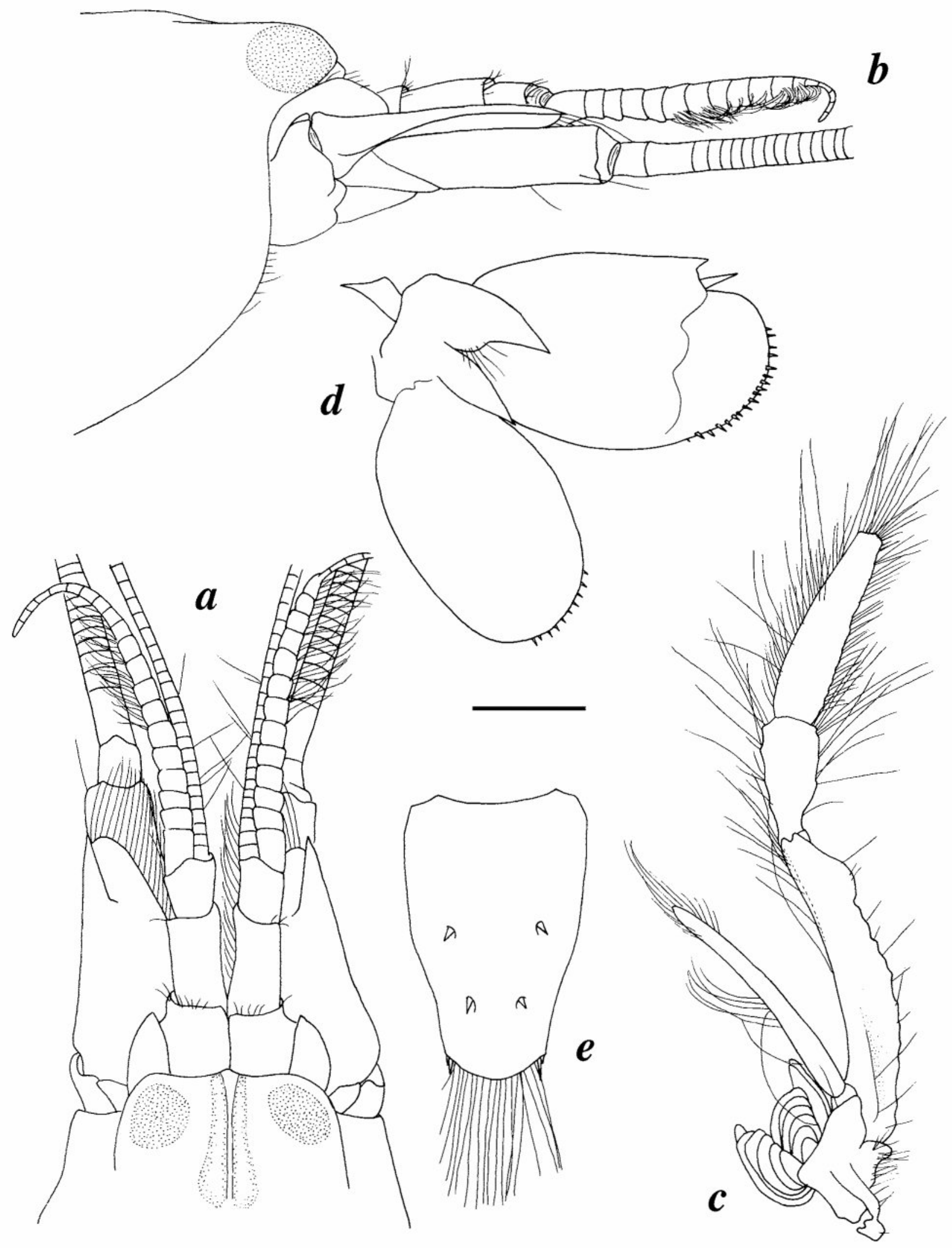

FIGURE 4. Alpheus christofferseni n. sp., male from Bocas del Toro, Panama (USNM 1100667): a, frontal region, dorsal view; b, same, lateral view; c, third maxilliped; d, right uropod, dorsal view; e, telson, dorsal view. Scale bar: 1 mm. 
armature (Fig. 3b, d); ischium armed with small ventrolateral spine; merus unarmed, about four (P3) to five (P4) times as long as wide; carpus unarmed; propodus with five spines along ventral margin and a pair of distal spines (Fig. 3b-e, i); dactylus simple, conical, not spatulate, gradually curved towards subacute tip, about 0.3 (P4) to $0.4(\mathrm{P} 3)$ propodus length (Fig. 3c, e). Fifth pereiopod much more slender than third and fourth pereiopods; ischium with small ventrolateral spine (Fig. 3f); merus about six times as long as wide; propodus with four spines on ventral margin (Fig. 3g), ventrolateral margin with five or six rows of grooming setae (Fig. 3f, g); dactylus simple, conical, about 0.45 propodus length, with some subdistal setae.
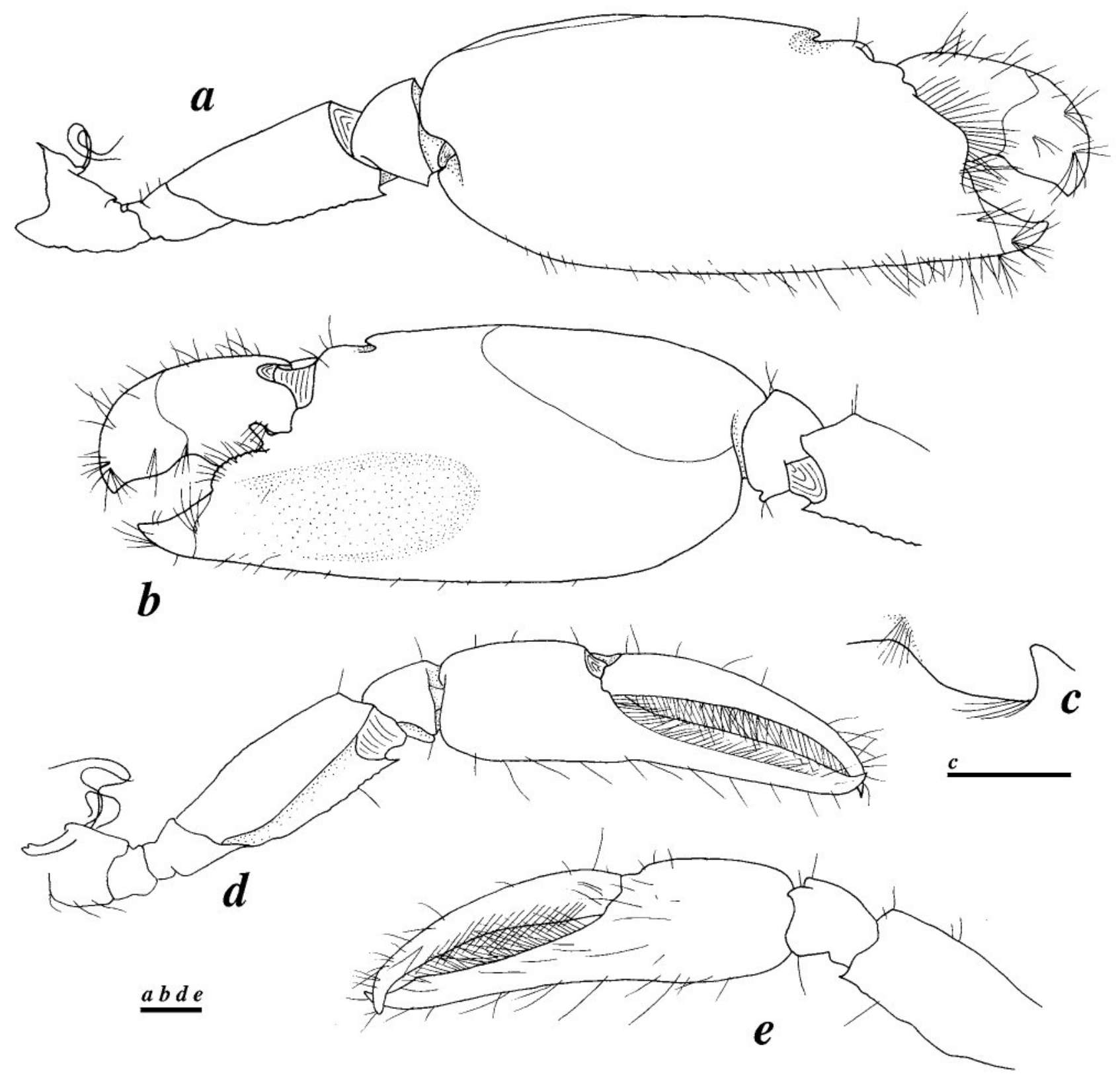

FIGURE 5. Alpheus christofferseni n. sp., male from Bocas del Toro, Panama (USNM 1100667): a, major cheliped, mesial view; b, same, distal merus, carpus and chela, lateral view; c, same, dactylus plunger, lateral view; d, minor cheliped, lateral view; e, same, distal merus, carpus and chela, mesial view. Scale bars: $1 \mathrm{~mm}$.

Abdominal somites with broadly rounded posteroventral margins; fifth somite with rounded-angular posteroventral margin; sixth segment without articulated flap, posterior margin straight, dorsolateral projections rounded; preanal plate rounded. Male second pleopod with appendix interna subequal to appendix masculina, latter with slender spine-like setae distally and along margin opposed to endopod (Fig. 1i). Uropod (Fig. 1f) with protopod bearing distally two strong acute teeth; exopod with diaeresis bearing one subtriangular lateral 
lobe proximal to distolateral spine and two well-marked rounded lobes at mid-length and mesially (Fig. 1g); lateral spine relatively strong, elongate; distal margins of exopod furnished with spinules (Fig. 1g). Telson relatively narrow, tapering towards posterior margin, with two pairs of short dorsal spines inserted at some distance from lateral margins, first pair at about mid-length, second pair at 3/4 of telson length (Fig. 1f); posterior margin broadly rounded, with one pair of small posterolateral spines at each angle, mesial spines being twice as long as lateral spines; anal tubercles well developed.

Gill/exopod formula typical for genus: 5 pleurobranchs (P1-5); 1 arthrobranch (Mxp3); 0 podobranch $($ Mxp2); 2 lobed epipods (Mxp1-2), 5 strap-like epipods = mastigobranchs (Mxp3, P1-4), 5 sets of setobranchs (P1-5); 3 exopods (Mxp1-3).

Color. No color notes were made for the four specimens from the Atol das Rocas type series. However, the specimen from Bocas del Toro was photographed alive (11a-c, 12b, c) and may be described as following: background mostly semitransparent, with numerous reddish chromatophores forming several diffuse bands, including a broad band running laterally on abdominal pleurae, and interconnecting with broad transverse bands on first, second, fourth, fifth and sixth somites; dorsal portion of carapace speckled with red chromatophores, latter arranged in a transverse band running along posterior margin of carapace and connecting to most-anterior transverse band on abdomen; central dorsal portions of abdominal somites colorless; tail fan, rostral region, antennular and antennal peduncles, and walking legs semitransparent, speckled (more or less densely) with red chromatophores; chelipeds hyaline-grey with red chromatophores arranged in patches and longitudinal bands in some areas, leaving other areas colorless; palm of major chela distally pale orange; fingers of both chelipeds ivory-pinkish (Fig. 11b, c).

Size. The CL of males ranges from 6.7 to $6.8 \mathrm{~mm}$, TL 19.7 to $20.1 \mathrm{~mm}$, respectively; the CL of females ranges from 6.1 to $7.1 \mathrm{~mm}$, TL 17.2 to $22.1 \mathrm{~mm}$, respectively.

Etymology. The new species is named after Dr. Martin L. Christoffersen (Universidade Federal de Paraíba, João Pessoa), for his significant contributions to the knowledge of the Brazilian alpheid and other caridean shrimps (see Christoffersen, 1998 and references therein).

Type locality. Atol das Rocas, Brazil.

Distribution. Western Atlantic: presently known only from the type locality, Atol das Rocas, off northeastern Brazil, and Bocas del Toro, Caribbean coast of Panama.

Ecology. The Atol das Rocas specimens were collected with the aid of a bait suction pump from burrows on an intertidal sand flat. The Bocas del Toro specimen was collected on a shallow $(0.5-1.0 \mathrm{~m})$ seagrass sand flat, about $15 \mathrm{~m}$ from a sand beach with a few mangrove trees, backed by a peat swamp (Fig. 12a). It was extracted with a bait suction pump from the possibly U-shaped burrow of a relatively large (body length 95 $\mathrm{mm}$, body diameter $15 \mathrm{~mm}$, proboscis length $10 \mathrm{~mm}$ ) thalassematid echiuran, Ochetostoma cf. edax (Fisher, 1946) (Fig. 12b, c).

Taxonomic remarks on host. Ochetostoma edax Fisher, 1946 (identification by G.-V. Murina) was originally described from Baja California in the eastern Pacific (Fisher, 1946) and was previously not known from the Atlantic Ocean (Stephen \& Edmonds, 1972). The individual from Bocas del Toro - host of A. christofferseni n. sp. (Fig. 12b, c) - was extracted with a suction pump from a vertical shaft-like burrow on a seagrass sandflat, whereas all eastern Pacific individuals of $O$. edax were found in horizontal burrows in muddy sand under rocks (see below). As noted by Anker et al. (2005) for Ochetostoma erythrogrammon Leuckart \& Rüppel, 1828, the paucity of morphological, anatomical and color-based characters in species-level taxonomy of the Echiura makes detection of cryptic taxa nearly impossible. Therefore, taxa with pantropical or transisthmian distributions, such as $O$. erythrogrammon, or $O$. edax, respectively, should also be examined genetically. For the time being, the Bocas del Toro specimen of Ochetostoma, which appears to be ecologically different from $O$. edax, is referred to as $O$. cf. edax, awaiting further taxonomic studies.

Variation. The new species appears to be variable in the shape of the rostrum: it may be extremely short and blunt, as in the specimen from Bocas del Toro (Fig. 4a), broad and triangular, as in the first paratype (Fig. 1h), or more slenderly triangular, as in the second paratype (Fig. 1a). The Bocas del Toro specimen also has a much broader telson compared to the Atol das Rocas type specimens (cf. Figs. 1f, 4e). A slight variation also exists in the ratio of carpal segments in the second pereiopods (cf. Figs. 3a, h, 6a). 

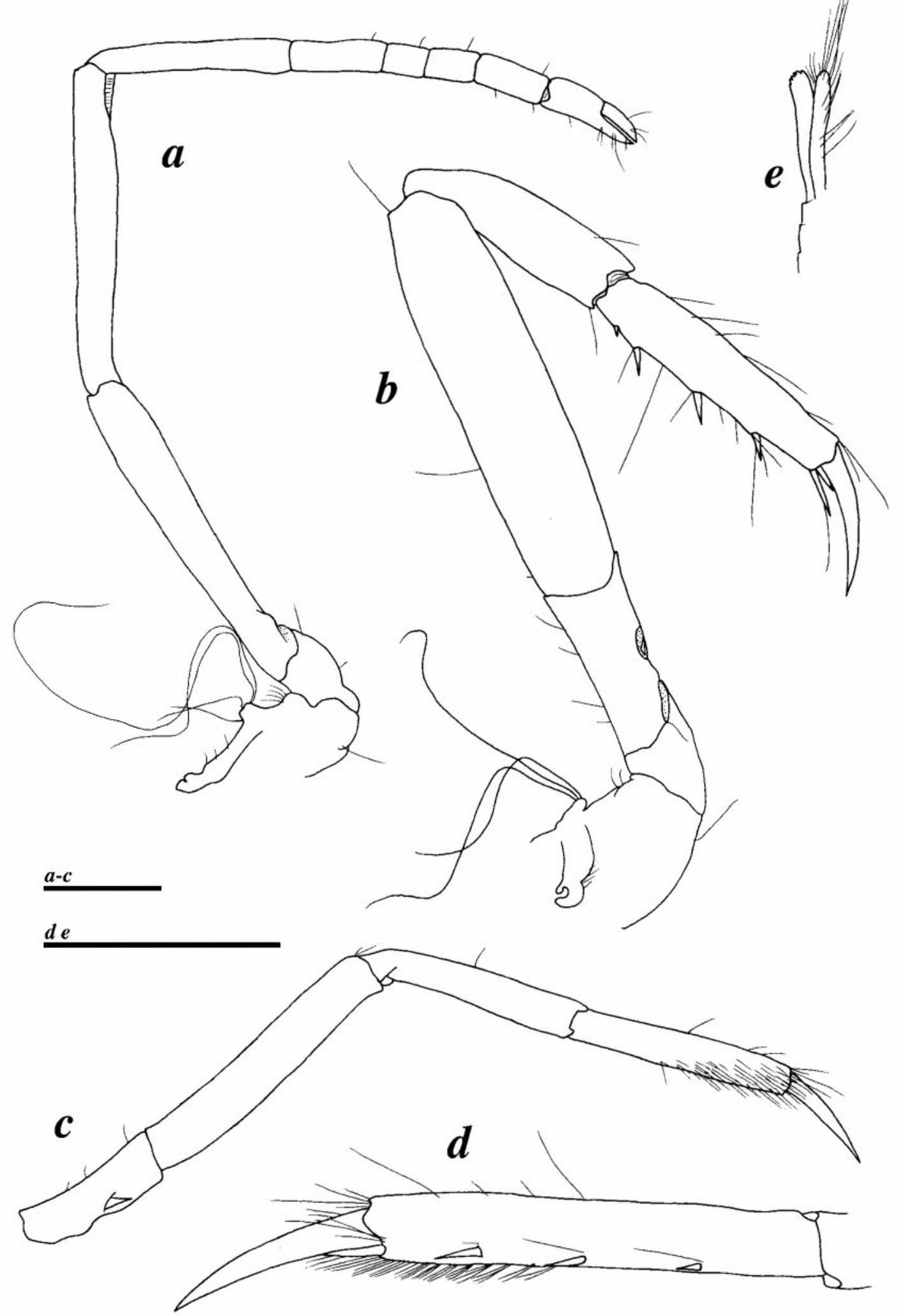

FIGURE 6. Alpheus christofferseni n. sp., male from Bocas del Toro, Panama (USNM 1100667): a, second pereiopod, lateral view; b, third pereiopod, lateral view; c, fifth pereiopod, lateral view; d, same, propodus and dactylus, ventral view; e, appendix masculina and appendix interna of second pleopod. Scale bars: $1 \mathrm{~mm}$. 
Remarks. Within the A. barbatus complex, A. christofferseni $\mathbf{n}$. sp. is morphologically most similar to the eastern Pacific A. aequus and to the below described A. naos n. sp. It differs from A. aequus by the presence of a large, acute tooth on the ventromesial margin of the merus of the major chelipeds. Kim \& Abele (1988) mentioned in the description of $A$. aequus that it has "no spine at distal end" on the "inferior inner" (ventromesial) margin of the merus of the major cheliped. This margin may be at most bluntly projecting, as in the two specimens of $A$. aequus from Coibita (Fig. 10b). The homologous tooth on the minor cheliped also separates these two species: it is present, although small, in A. christofferseni n. sp., and absent in A. aequus (Kim \& Abele, 1988). Furthermore, A. christofferseni $\mathbf{n}$. sp. differs from $A$. aequus by the somewhat longer and more slender major chela (cf. Figs. 2a, b, 5a, b, 10b, c). The main differences between A. christofferseni $\mathbf{n}$. sp. and $A$. naos n. sp. are the length of the stylocerite: not reaching distal margin of first antennular segment in $A$. christofferseni $\mathbf{n}$. sp. vs. reaching or almost reaching this margin in A. naos $\mathbf{n}$. sp.; and the shape of the rostral carina: very narrow in A. christofferseni n. sp., broader in A. naos n. sp. (cf. Figs. 1a, 4a, 7a). Alpheus christofferseni $\mathbf{n}$. sp. may be separated from the eastern Atlantic $A$. ribeiroae by the shape of the scaphocerite, with distolateral spine distinctly exceeding the anterior margin of the blade (not exceeding in A. ribeiroae); fingers of the minor chela bearing dense rows of setae (absent in A. ribeiroae); and a stouter major cheliped, which differs in the palm/finger ratio (cf. Anker \& Dworschak, 2004). Finally, the western Atlantic species, as well as both eastern Pacific species (see below) differ from the Indo-West Pacific A. barbatus in several characters, e.g., by the proportions of the major chela, the less dense setal brushes on the fingers of the minor chela, and the much more elongate and narrower scaphocerite (cf. Banner \& Banner, 1982).

The color pattern of $A$. christofferseni $\mathbf{n}$. sp. appears to be nearly identical to that of A. aequus (cf. Fig. 11), and (although less intense) is also similar to the color pattern of $A$. naos $\mathbf{n}$. sp. (see below). The only noticeable differences between A. christofferseni n. sp. and A. naos n. sp. is that the posterior dorsal half of the carapace of $A$. christofferseni $\mathbf{n}$. sp. is covered with small reddish chromatophores (Fig. 11b), which are absent in A. naos n. sp. (Fig. 11d). However, in both A. christofferseni $\mathbf{n}$. sp. and A. naos $\mathbf{n}$. sp., the red bands may increase in intensity or fade away (almost disappearing completely, cf. Figs. 11a, b) depending on the shrimp's condition, which may be affected by stress, exposure to light, etc. Nomura (2000) attributed a similar color variation in A. barbatus to "the brightness of the day and night". However, the color variation in A. barbatus is more pronounced, especially on the major chela (cf. Nomura, 2000, fig. 1B, F). Both color and morphological variation in A. barbatus suggest presence of at least two cryptic species in the Indo-West Pacific (A. Anker, pers. obs.).

GenBank number. EF092273 (fcn AA-AC-41, MNRJ 17926); EF092274 (fcn 05-019, USNM 1100667).

\section{Alpheus naos n. sp.}

Figs. 7-9, 11d, e

Material examined. 1 male (CL 6.8, TL 20.1), USNM 1100668, Panama, Pacific coast, Amador causeway near Panama City, Punta Culebra, rocky shore, under large mud-covered rocks on muddy sand, in burrow of Listriolobus sp. (host collected and preserved), extreme low tide, 2 Mar 2006, coll., A. Anker and C. Hurt [fen 06-270].

Description. Carapace smooth, not setose, laterally not compressed. Rostrum short, subtriangular, distally subacute (Fig. 7a), slightly descendant and situated below dorsal-most portion of orbital hoods (Fig. 7b); mediorostral carina feebly marked, blunt, reaching beyond eye level, posteriorly flattening (Fig. 7a); orbitorostral grooves very shallow; orbitorostral process not conspicuous. Orbital hoods moderately inflated, rounded, unarmed (Fig. 7a). Pterygostomial angle rounded, not protruding (Fig. 7b). Branchiostegial margin fringed with setae. Eyes completely concealed in dorsal, lateral and partly frontal view. Ocellar beak welldeveloped, protruding vertically towards rostrum. Epistomial sclerite without projecting tooth. 


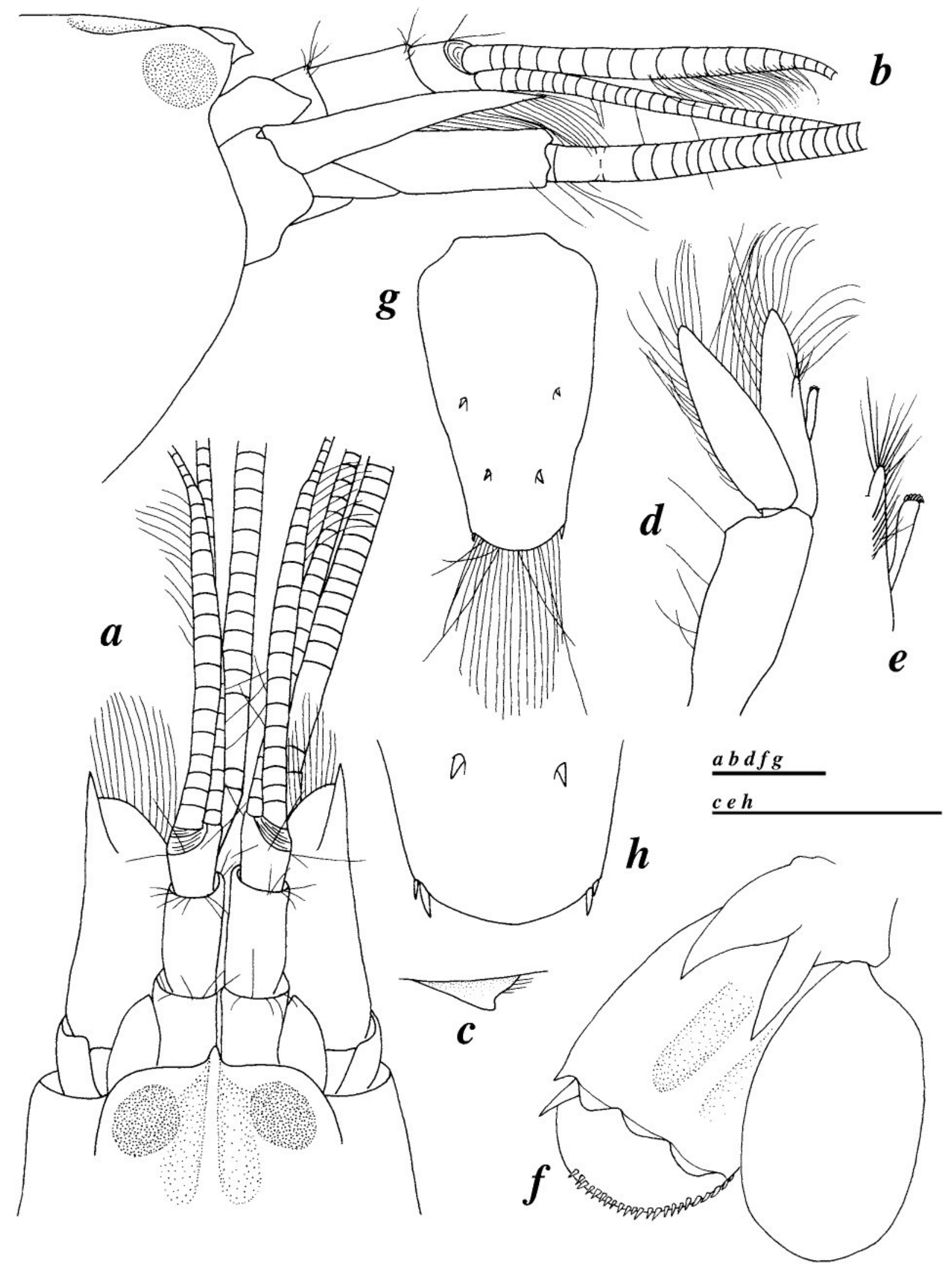

FIGURE 7. Alpheus naos n. sp., male holotype from Punta Culebra, Isla Naos, Panama (USNM 1100668): a, frontal region, dorsal view; b, same, lateral view; c, tooth on mesioventral carina of first antennular segment, lateral view; d, second pleopod, lateral view; e, same, appendix masculina and appendix interna; f, left uropod, dorsal view; g, telson, dorsal view; h, same, detail of posterior margin. Scale bars: $1 \mathrm{~mm}$. 


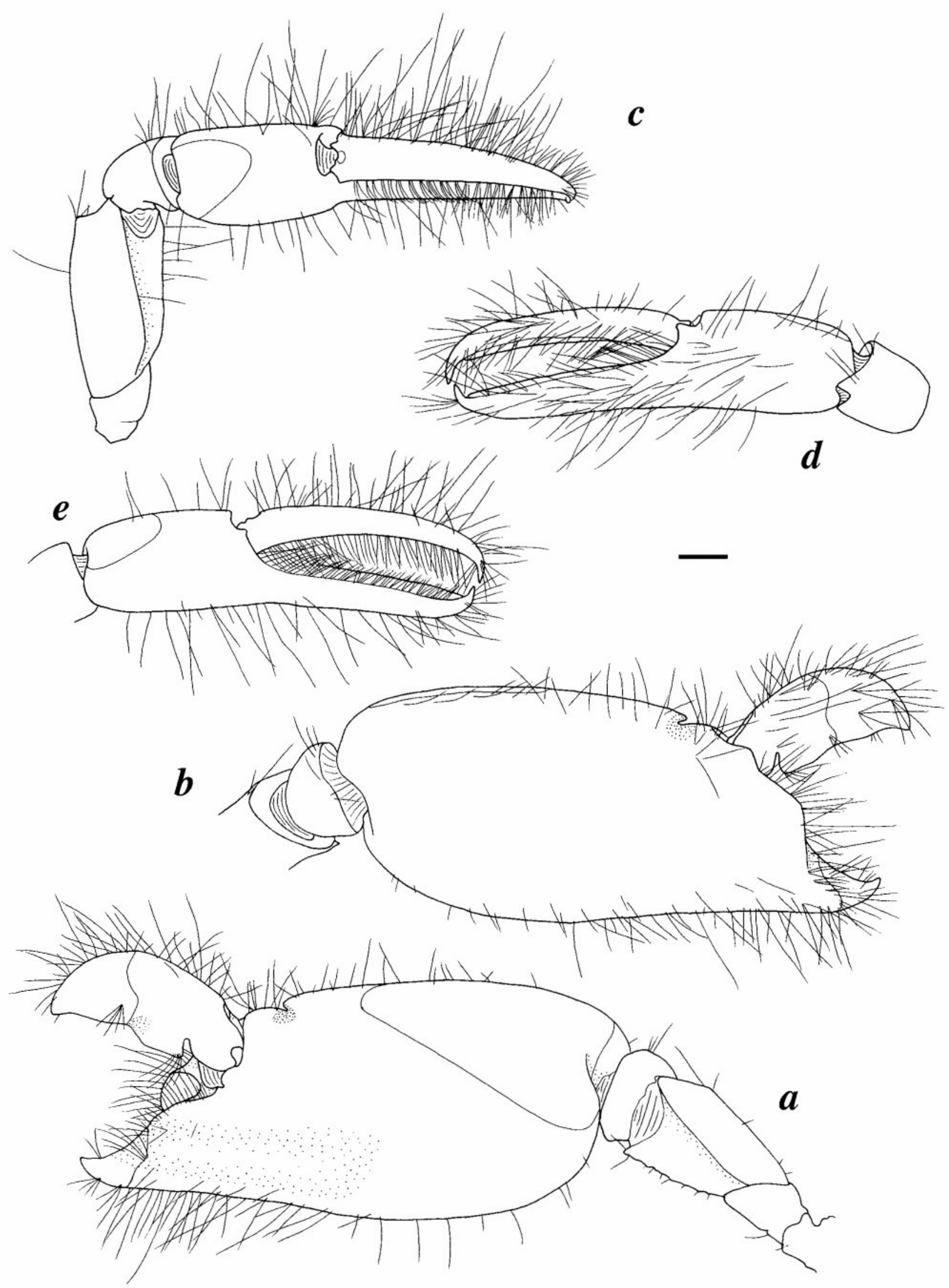

FIGURE 8. Alpheus naos n. sp., male holotype from Punta Culebra, Isla Naos, Panama (USNM 1 100668): a, major cheliped, lateral view; b, same, distal merus, carpus and chela, mesial view; c, minor cheliped, dorsolateral view; d, same, chela, mesial view; e, same, lateral view. Scale bar: $1 \mathrm{~mm}$. 


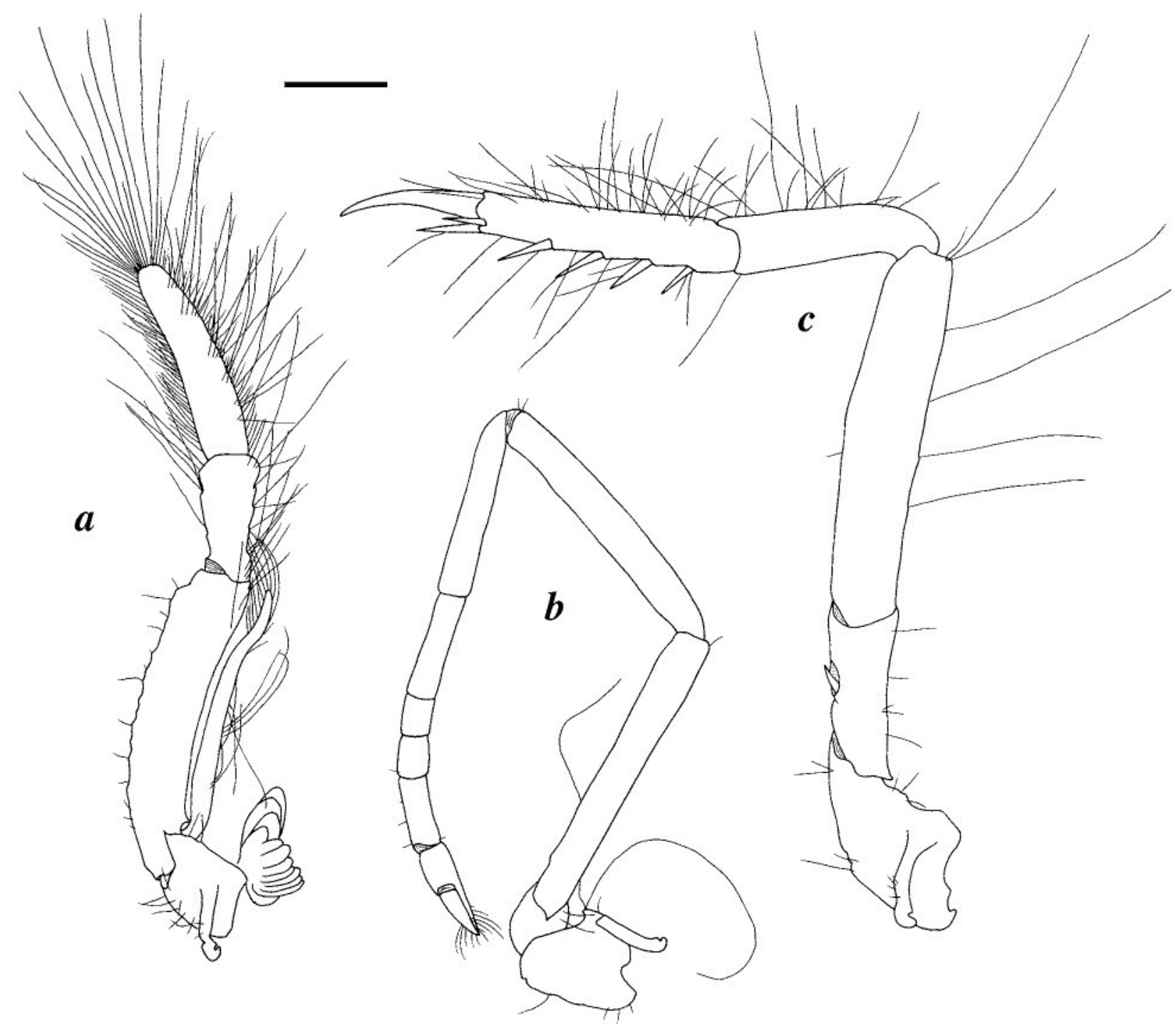

FIGURE 9. Alpheus naos n. sp., male holotype from Punta Culebra, Isla Naos, Panama (USNM 1100668): a, third maxilliped, lateral view; b, second pereiopod, lateral view; c, third pereiopod, lateral view. Scale bar: $1 \mathrm{~mm}$.

Antennular peduncles moderately stout, second segment slightly longer than dorsally visible portion of first segment, about 1.7-1.9 times as long as wide (Fig. 7a); stylocerite short, distally blunt, almost reaching distal margin of first segment (Fig. 7a); mesioventral carina of first segment with tooth as illustrated (Fig. 7c); lateral flagellum without independent secondary ramus, groups of aesthetasc tufts present starting from about ninth segment (Fig. 7a, b). Antenna with basicerite lacking ventrolateral tooth (Fig. 7b); carpocerite robust, reaching slightly beyond distal margin of antennular peduncle and scaphocerite; scaphocerite exceeding distal margin of antennular peduncle, with deep cleft between distolateral tooth and blade, lateral margin almost straight (Fig. 7a), distolateral tooth reaching well beyond anterior margin of blade (Fig. 7a).

Mouthparts (mandible, maxillule, maxilla, first and second maxillipeds) typical for Alpheus. Third maxilliped moderately stout (Fig. 9a); coxa with lateral plate ear-shaped, distally acute, furnished with some setae; antepenultimate segment flattened, with ventral margin somewhat rugose; ultimate segment very setose; exopod reaching penultimate segment; arthrobranch well-developed (Fig. 9a).

Major cheliped (Fig. 8a, b) with short, robust ischium; merus stout, about twice as long as wide, dorsal margin distally blunt, not projecting, ventromesial margin finely toothed, distally with small blunt tooth (Fig. 
8a); carpus cup-shaped, without distinct distal lobes; chela ovate, laterally compressed, subrectangular in cross-section; dorsal margin of palm with deep transverse notch subdistally (Fig. 8a, b), forming a broadly Ushaped groove in dorsal view; mesial face of palm smooth except for small depression near dorsal notch (Fig. $8 \mathrm{~b}$ ); lateral face with small depression near dorsal notch and broad, very shallow depression extending from base of pollex to about mid-length of palm (Fig. 8a); slightly more than 1/2 length of palm; dactylus with short, distally truncate plunger, latter with stamen-shaped sensillae (Figs. 8a. b); adhesive discs small (Fig. $8 a)$.

Male minor cheliped (Fig. 8c-e) with robust merus, more than twice as long as wide; dorsal margin distally unarmed; ventromesial margin straight, distally blunt (Fig. 8c); carpus short, cup-shaped, with blunt distomesial lobe; chela with palm about $3 / 5$ as long as fingers, without sculpture, ventral margin almost straight (Fig. 8d, e), distomesial margin with promenent blunt tooth (Fig. 8d); fingers long, slender, slightly gaping, laterally and mesially with rows of stiff setae along cutting edges, tips crossing when chela closed (Fig. 8d, e). Female minor cheliped unknown.

Second pereiopod relatively slender; ischium slightly longer than merus; carpus with five articles, with ratios (from proximal to distal) of approximately $5: 3: 1: 1: 2$ (Fig. 9b); chela simple, with fingers subequal to palm; palm as long as distal carpal article. Third pereiopod (Fig. 9c) with ischium bearing one ventrolateral spine; merus unarmed, at least five times as long as wide; carpus unarmed; propodus with four slender spines along ventral margin and a pair of distal spines (Fig. 9c); dactylus simple, conical, not spatulate, gradually curved towards subacute tip, about $1 / 2$ propodus length. Fourth pereiopod similar to third. Fifth pereiopod with different article proportions; ischium with ventrolateral spine; propodus with ventral spines and welldeveloped setal brush.

Abdominal somites with broadly rounded posteroventral margins; fifth somite with rounded-angular posteroventral margin; sixth segment without articulated flap, posterior margin straight, dorsolateral projections rounded; preanal plate rounded. Male second pleopod (Fig. 7d) with appendix masculina longer than appendix interna, possibly partly fused to endopod, with slender spine-like setae distally and along endopod-facing margin (Fig. 7d, e). Uropod (Fig. 7f) with protopod bearing distally two strong acute teeth; exopod with diaeresis bearing one subtriangular lateral lobe proximal to distolateral spine and two well-marked rounded lobes at mid-length and mesially; lateral spine relatively strong, elongate; distal margins of exopod furnished with spinules (Fig. 7f). Telson relatively narrow, tapering towards posterior margin (Fig. $7 \mathrm{~g}$ ), with two pairs of short dorsal spines inserted at some distance from lateral margins, first pair at about mid-length, second pair at 3/4 of telson length (Fig. $7 \mathrm{~g}$ ); posterior margin broadly rounded, with one pair of small posterolateral spines at each angle, mesial spines being at least twice as long as lateral spines (Fig. 7h); anal tubercles well-developed.

Gill/exopod formula as indicated for previous species.

Color. Background mostly white semitransparent, with numerous red chromatophores forming several bands, including a broad lateral band on abdominal pleurae, interconnecting with two broad transverse bands on second and fifth somites, and narrow, more irregular bands on first and fourth somites, sixth somite with narrow transverse band along posterior margin; telson and uropods red except for most proximal portions; dorsal portion of carapace with broad band of red chromatophores, descending to flanks; central dorsal portions of abdominal somites, especially third, fourth and sixth, as well as most of posterior and anterior carapace colorless; rostral region, anterolateral margins of carapace and antennular peduncles semitransparent speckled (more or less densely) with red chromatophores; antennal peduncle and walking legs mostly semitransparent white; cheliped merus and carpus hyaline white with red chromatophores; chelae pinkish red due to numerous red chromatophores, distally (proximal to fingers) with pale orange tinge; fingers of major and minor chelae mostly ivory white (Fig. 11d, e).

Size. The CL of the holotype male specimen is $6.8 \mathrm{~mm}$, TL $20.1 \mathrm{~mm}$.

Etymology. The new species is named after Isla Naos, where the type locality (Punta Culebra) and the Naos Marine Laboratory of the STRI are situated. 
Type locality. Punta Culebra, Isla Naos, Amador Causeway near Panama City, Pacific coast of Panama.

Distribution. Eastern Pacific: presently known only from the type locality on the Pacific coast of Panama.

Ecology. The holotype was collected by hand from a burrow of a large thalassematid echiuran (body length $150 \mathrm{~mm}$, body diameter 10-15 mm, proboscis length $30 \mathrm{~mm}$ ), Listriolobus $\mathrm{sp}$. (see below). The burrow was dug horizontally into muddy sand under large mud-covered rocks, in the rocky intertidal, near the extreme low tide mark.

Taxonomic remarks on host. The original identification of the host as "Listriolobus sp. aff. brevirostris Chen \& Yeh, 1958" was tentative (G.-V. Murina, pers. comm.), partly because of the imperfect condition of the specimen from Punta Culebra (the animal died a few hours prior to preservation). Listriolobus brevirostris was originally described from China (Chen \& Yeh, 1958; Stephen \& Edmonds, 1972) and is not known to occur in the eastern Pacific. On the other hand, specimens of its congener, Listriolobus cf. bahamensis Fisher, 1926, were recently collected at Punta Culebra and other localities along the Pacific coast of Panama (Murina \& Anker, in prep.). They are morphologically (at least externally) and ecologically very similar to the individual found with A. naos $\mathbf{n}$. sp. As no other species of Listrilobus are known from the shallow waters of the tropical eastern Pacific (Stephen \& Edmonds, 1972), L. cf. bahamensis may well be the host of A. naos n. sp.

Remarks. Within the A. barbatus complex, A. naos $\mathbf{n}$. sp. is morphologically closest to the eastern Pacific A. aequus and the western Atlantic $A$. christofferseni n. sp. (see above). It differs from $A$. aequus by the slightly narrower telson; the slightly longer second segment of the antennular peduncle; the broader blade of the scaphocerite; the lack of a slight sinus on the ventral margin of the palm of the minor chela; the less gaping fingers of the minor chela; a different palm/fingers ratio of the major chela; and the distinctly narrower merus of the third pereiopod. For differences between A. christofferseni $\mathbf{n}$. sp. and A. naos n. sp. see remarks under the former species. Another possible difference between these two species may lie in the appendix masculina: its proximal half is apparently partly fused to the endopod in A. naos n. sp. (Fig. 7e), whereas the entire appendix masculina is free-standing in A. christofferseni n. sp. (Figs. 1i, 6e) All these features, however, need to be confirmed by observations in additional specimens.

GenBank number. EF092275 (fcn 06-270, USNM 1100668).

\section{Alpheus aequus Kim \& Abele, 1988}

Figs. 10, 11f

Alpheus aequus Kim \& Abele, 1988: 55, fig. 23; Wicksten \& Hendrickx, 1992: 4; Ramos, 1995: 145, fig. 9; Vargas \& Cortés, 1999: 898; Wicksten \& Hendrickx, 2003: 63.

Material examined. 1 female (CL 4.7, TL 14.3), MNHN-Na 16388, Panama, Coiba Marine National Park, Coibita, mud-rock intertidal, under rock, in burrow of Ochetostoma edax (host collected and preserved), extreme low tide, 20 Mar 2007, coll. A. Anker, I. Marin, J. Jara, E. Gómez and E. Tóth [fen 07-109]; 1 ovig. female (CL 4.9, TL 14.3), MNHN-Na 16389, Panama, Coiba Marine National Park, Coibita, mud-rock intertidal near STRI station, under rock, in burrow of Ochetostoma edax (host collected and preserved), extreme low tide, 22 Mar 2007, coll. A. Anker [fen 07-177].

Description. For detailed description see Kim \& Abele (1988).

Color. Mostly ivory-whitish with pinkish tinge in some areas due to presence of scattered reddish chromatophores (Fig. 11f); one female had yellow-orange eggs.

Size. The CL of the two females is $4.7 \mathrm{~mm}$ and $4.9 \mathrm{~mm}$, the TL for both is $14.3 \mathrm{~mm}$. The single male originally reported by Kim \& Abele (1988) had a CL of $4.3 \mathrm{~mm}$, whereas the two females both had a CL of 6.8 $\mathrm{mm}$. Ramos' (1995) three specimens were smaller, with $2.9 \mathrm{~mm} \mathrm{CL}$ in the single male and $4.3-4.4 \mathrm{~mm}$ in the two females. Based on these data, the CL of adult A. aequus ranges from 2.9 to $6.8 \mathrm{~mm}$. 


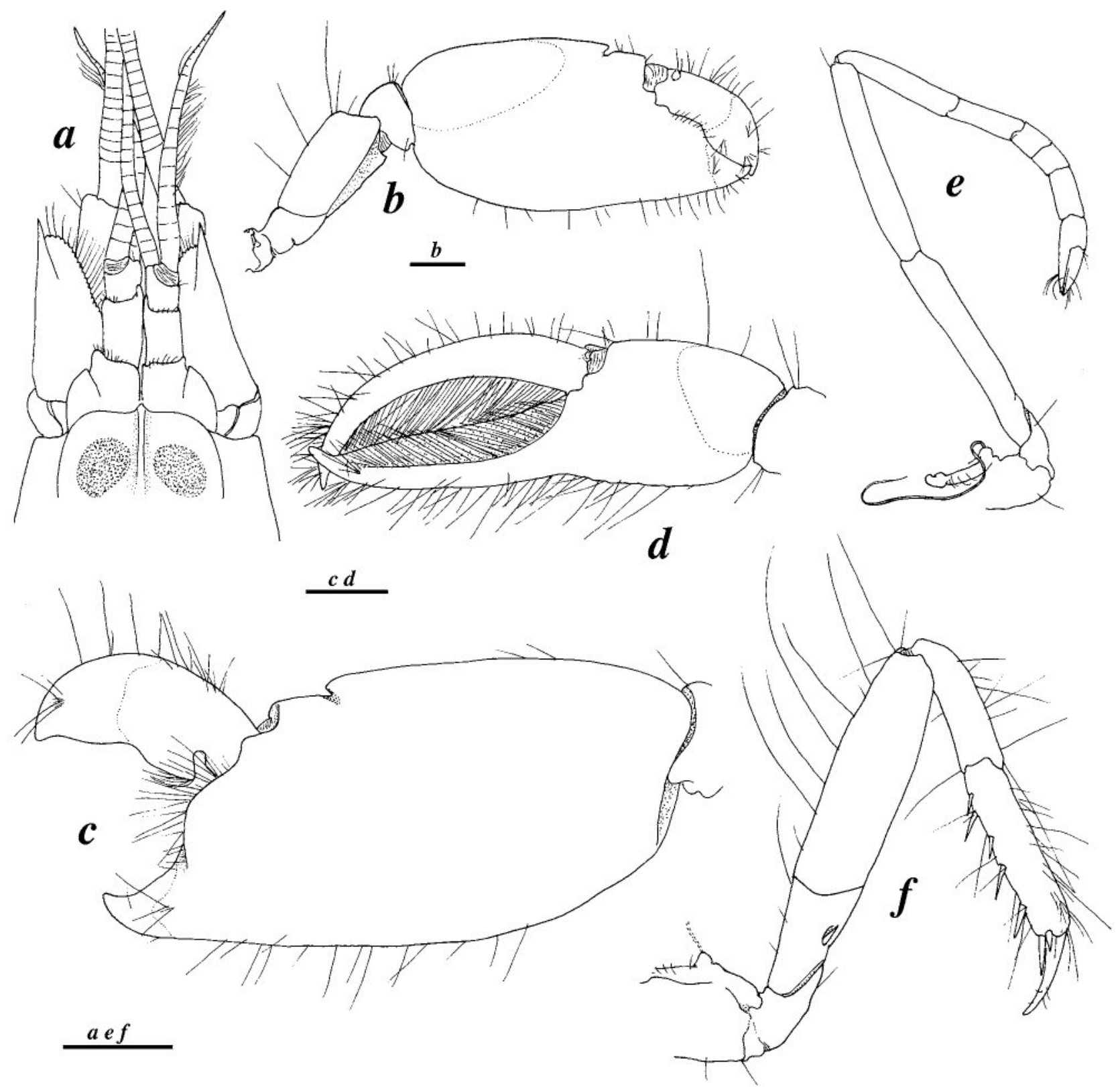

FIGURE 10. Alpheus aequus Kim \& Abeke, 1988, female from Coibita, Coiba Marine National Park, Panama (MNHN 16389): a, frontal margin, dorsal view; b, major cheliped, lateral view; c, same, chela, mesial view; d, minor chela, lateral view; e, second pereiopod, lateral view; f, third pereiopod, lateral view. Scale bars: $1 \mathrm{~mm}$.

Type locality. Playa Blancas, Costa Rica (Kim \& Abele, 1988).

Distribution. Eastern Pacific: Costa Rica: Playa Blancas; Galapagos: Santa Fe (Kim \& Abele, 1988); Panama: Coibita (Coiba Marine National Park) (present study); Colombia: Gorgona Island (Ramos, 1995).

Ecology. The habitat of the holotype from Playa Blancas, Costa Rica, was described as "shore to $5.0 \mathrm{~m}$; shale beach" and "shale beach between beach and rocky reef" (Kim \& Abele, 1988). Other alpheids collected in this area were Alpheus fasciatus Lockington 1878 (reported as A. paracrinitus Miers, 1888) and A. galapagensis Sivertsen, 1933 (reported as A. canalis Kim \& Abele, 1988). The two specimens from Santa Fe (Barrington) Island, Galapagos, were collected while "diving in bay, [at] about $5 \mathrm{~m}$ ". Other alpheids occurring in this locality were Alpheus bellimanus Lockington, 1878 and A. rostratus Kim \& Abele, 1988. Ramos' (1995) specimens came from a tidal beach with coral sand ("playas de arena coralina"). No particular associations were noted by Kim \& Abele (1988) or Ramos (1995). In contrast, the two Panamanian specimens of $A$. 
aequus were found associated with medium-sized (body length $28 \mathrm{~mm}$, diameter 11-12 $\mathrm{mm}$, proboscis length $15 \mathrm{~mm}$, proboscis diameter 3-5 mm) thalassematid echiurans, Ochetostoma edax (Fisher, 1926) (Fig. 12e) in a mixed mud-rock intertidal of Coibita (Fig. 12d). The burrows of $O$. edax are smoothly lined horizontal tunnels dug in muddy sand under partly mud-embedded rocks. The shrimps were observed sitting just next to their hosts. Notably, in both cases, only one shrimp per host was found, despite some efforts to find its potentially present mate by prospecting the immediate vicinity of the burrow.

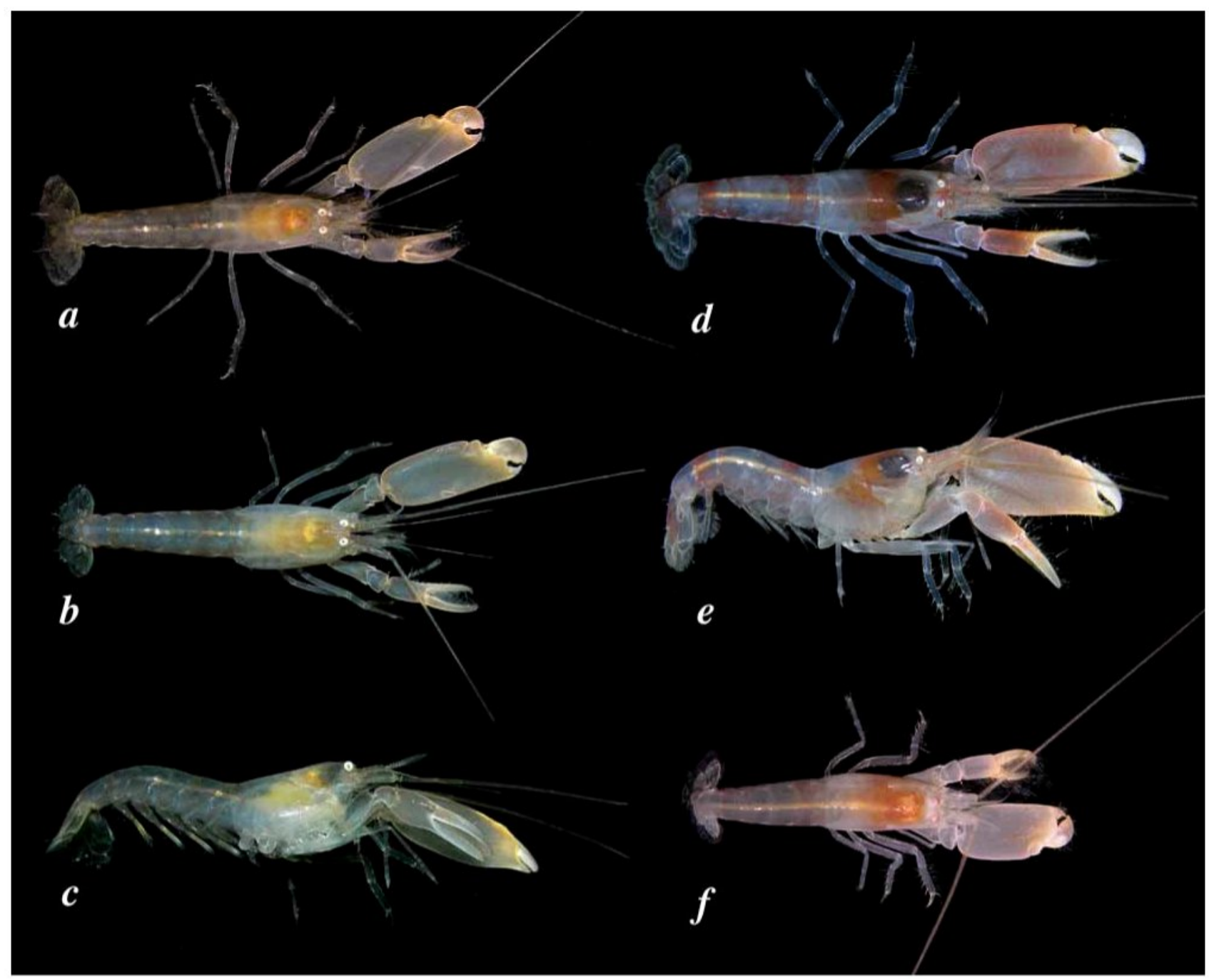

FIGURE 11. Color patterns in life. Alpheus christofferseni $\mathbf{n}$. sp., male from Bocas del Toro, Panama (USNM 1100667) (a-c): a, b, dorsal view (note partly faded chromatopores in a); c, same, lateral view. Alpheus naos n. sp., male holotype from Punta Culebra, Isla Naos, Panama (USNM 1100668) (d, e): d, dorsal view; e, lateral view. Alpheus aequus Kim \& Abele, 1988, female from Coibita, Coiba Marine National Park, Panama (MNHN-Na 16389) (f): dorsal view.

Taxonomic remarks on host. The finding of two specimens of Ochetostoma edax (identification by G.-V. Murina) at Coibita represents a considerable extension of the distribution range of this species from Baja California to Panama. The identity of $O$. cf. edax from the Atlantic (Caribbean) coast of Panama remains to be determined (see above).

Variation. The two female specimens from Coibita agree well with the description and illustrations of $A$. aequus provided by Kim \& Abele (1988), except for the length of the dactylus of the major chela, which reaches only slightly beyond the tip of the pollex in the Coibita specimens, and distinctly beyond the pollex in the holotype (cf. Kim \& Abele 1988, fig. 23).

GenBank number. EU084881 (fcn 07-109, MNHN 16388). 

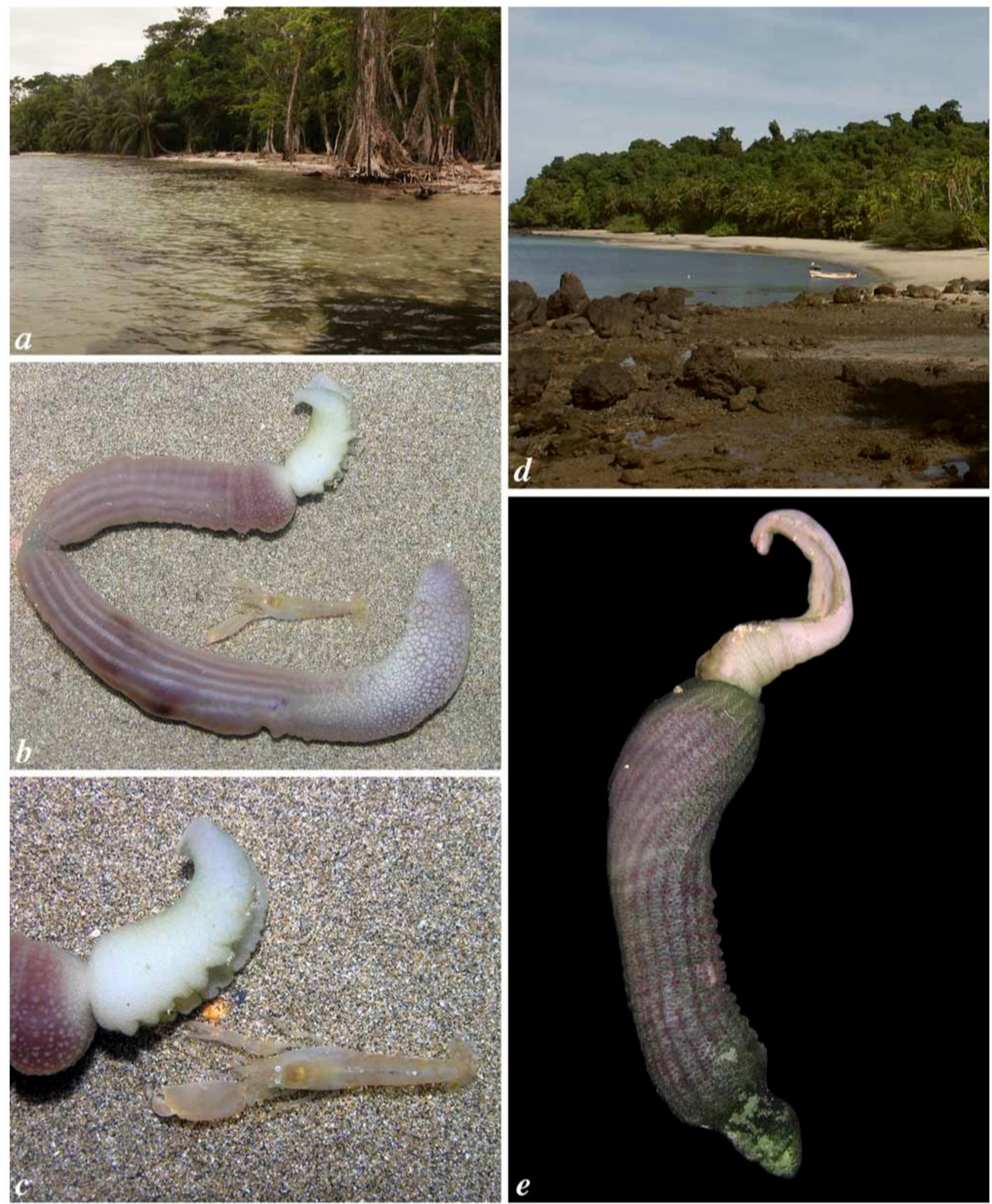

FIGURE 12. Habitats and hosts: a, shallow subtidal sandflat with patches of flotting algae and seagrass at Carenero Island, Bocas del Toro, Panama, type locality of Alpheus christofferseni n. sp.; b, c, Alpheus christofferseni n. sp. with host, Ochetostoma cf. edax (Fisher, 1946) (Echiura, Thalassematidae), a few hours after collection; d, partly exposed rock-mud intertidal at Coibita, Coiba Marine National Park, Panama, one of collection sites of Alpheus aequus Kim \& Abele, 1988; e, Ochetostoma edax (Echiura, Thalassematidae), host of the Coibita specimen (MNHN-Na 16389). 


\section{Discussion}

Christoffersen (1998) listed 23 species of Alpheus occurring on Brazilian coasts. Recently, Coelho (2006) added two more species to this list. The present description of $A$. christofferseni $\mathbf{n}$. sp. raises the total number of Brazilian Alpheus species to 26. However, since a number of western Atlantic/eastern Pacific or amphiAtlantic/eastern Pacific species, such as A. armillatus H. Milne-Edwards, 1837, A. bouvieri A. MilneEdwards, 1878, A. formosus Gibbes, 1850, A. floridanus Kingsley, 1878, A. normanni Kingsley, 1878 and $A$. cylindricus Kingsley, 1878, are actually species complexes (Knowlton \& Mills, 1992; Knowlton et al., 1993; Anker, 2001b) and need taxonomic revisions, further changes are expected. These changes will include nomenclatural changes of species names due to resurrection of old synonyms, as well as descriptions of new taxa, which will further increase the total number of species. Furthermore, for most of these alpheids it remains to be shown that the Brazilian material belongs to the same species as the material from the Caribbean or Florida; if these forms are shown to be different, it would result in further species splitting. Brazilian alpheids studied by Williams et al. (2001) exhibit a range of divergences from their closest Caribbean relatives.

No less than 75 species of Alpheus occur on the Caribbean and Pacific coasts of Panama (Chace, 1972; Kim \& Abele, 1988; Anker, unpubl.), but until now none of them were known as symbionts ("commensals") of other burrowing animals. Worldwide, there are only a few reports of Alpheus species living in burrows of other animals, mostly brachyuran crabs (Schmitt, 1926; Silliman et al., 2003). The independent findings of specimens of the western Atlantic A. christofferseni n. sp. and the eastern Pacific A. naos $\mathbf{n}$. sp. and A. aequus in burrows of morphologically and ecologically similar innkeeper worms from the family Thalassematidae suggest that all three species live "commensally" in echiuran burrows. This assumption is supported by two previous reports of associations between the closely related A. barbatus and thalassematid echiurans in the western Pacific (Tzeng \& Chen, 1992; Nomura, 2000; see also Anker et al., 2005 for review). All these findings suggest that the symbiosis between these snapping shrimps and echiurans has evolved in the ancestor of the A. barbatus clade and is so relatively ancient.

The K2P genetic distance estimate between the two Atlantic populations (Brazil and Panama) of A. christofferseni $\mathbf{n}$. sp. was $2.6 \%$ ( $5^{\prime}$ end only, one specimen from each population). Decisions about species definitions in allopatry depend on the nature of the species concept being used (see discussion in Knowlton \& Weigt, 1997 for other alpheids). For example, any fixed genetic difference would be adequate for some versions of the phylogenetic species concept. However, the level of divergence between these two taxa is less than any observed across the Isthmus, and interpreting the significance of the subtle morphological and genetic differences observed is difficult with the limited material in hand. With only one sequence from each population it is impossible to know if the above distance falls within the range of what is seen within populations. For this reason we prefer to use the same name for both the Caribbean and Brazilian forms (although later work may suggest that the Caribbean taxon merits separate subspecies status).

On the other hand, A. christofferseni $\mathbf{n}$. sp. differs genetically from A. naos n. sp. by $15.8 \%$, and from $A$. aequus by $17.9 \%$; the latter two species differ from each other by $14.5 \%$. Assuming a molecular clock of $1.5 \%$ sequence divergence per million years (see Methods), this corresponds to $\sim 11-12$ million years of separation between the western Atlantic A. christofferseni n. sp. and the eastern Pacific clade A. naos n. sp. - A. aequus, and $\sim 10$ mya between the two eastern Pacific species. The transisthmian difference is greater than that observed between 13 of the 15 other transisthmian alpheid taxa previously studied (Knowlton \& Weigt, 1998), and all transisthmian taxa studied to date are strongly isolated reproductively (Knowlton et al., 1993). The two eastern Pacific species are older than most other sympatric sister species studied to date (cf. Knowlton et al., 1993; Knowlton \& Weigt, 1998; Williams et al., 2001). Thus our genetic results fully support a separate species status for A. christofferseni $\mathbf{n}$. sp. and A. naos n. sp., despite their similarity in morphology and color to each other and to $A$. aequus. This constitutes another example of a transisthmian evolutionary stasis (between 
A. christofferseni n. sp. and the two eastern Pacific taxa), and of a finely tuned, perhaps ecological sympatric speciation (between A. naos n. sp. and A. aequus).

The A. barbatus complex clearly needs further phylogenetic, ecological and taxonomic studies. For instance, A. barbatus may contain further cryptic taxa in the Indo-West Pacific. The eventual host of the eastern Atlantic A. ribeiroae is unknown. The phylogenetic relations of A. ribeiroae and A. barbatus to the American species also remain undetermined. Currently available data suggests that Ochetostoma spp. were ancestral hosts in the A. barbatus clade, and that A. naos n. sp. possibly switched to Listrilobus. However, more shrimp specimens of all three species with their hosts are needed to enable further studies. DNA analyses of shrimp's hosts (echiurans) are desirable to investigate eventual coevolutionary patterns between these unusual snapping shrimps and their echiuran hosts, as well as presence of cryptic species in transisthmian echiurans.

\section{Acknowledgments}

We are grateful to the late Dr. Paolo Young (formerly at Museu Nacional, Rio de Janeiro, Brazil) and all members of the Atol das Rocas invertebrate project for collecting specimens and making them available for study. Dr. Galena-Vantsetti Murina (Institute of Biology of the Southern Seas, National Academy of Sciences of Ukraine, Sevastopol, Ukraine) kindly identified the echiuran hosts. This study was supported by funds from the John Dove Isaacs Professorship of Natural Philosophy at the Scripps Institution of Oceanography, La Jolla, USA, and the Smithsonian Tropical Research Institute, Panama City, Panama (NK), and is part of the Census of Marine Life/CReefs Project. We also thank the Autoridad Nacional del Ambiente (ANAM) for collection permits in Panama.

\section{References}

Anker, A. (2000) Taxonomical problems of goby-associated species of Alpheus (Decapoda, Alpheidae). IOP Diving News, 11, 2-7.

Anker, A. (2001a) Taxonomie et évolution des Alpheidae (Crustacea, Decapoda). PhD Thesis, Muséum national d'Histoire naturelle, Paris, 2 vols, $547+331 \mathrm{pp}$.

Anker, A. (2001b) Two new species of snapping shrimps from the Indo-Pacific, with remarks on colour patterns and sibling species in Alpheidae (Crustacea: Caridea). Raffles Bulletin of Zoology, 49, 57-72.

Anker, A., Ahyong, S.T., Noël, P.Y. \& Palmer, A.R. (2006) Morphological phylogeny of alpheid shrimps: parallel preadaptation and the origin of a key morphological innovation, the snapping claw. Evolution, 60, 2507-2528.

Anker A. \& Dworschak, P.C. (2004) A new species of Alpheus from the tropical eastern Atlantic (Crustacea: Decapoda: Alpheidae). Annalen des Naturhistorischen Museums in Wien, 105B, 47-58.

Anker A., Murina, G.V., Lira, C., Vera Caripe, J.A., Palmer, A.R. \& Jeng, M.S. (2005) Macrofauna associated with echiuran burrows: a review with new observations of the innkeeper worm, Ochetostoma erythrogrammon Leuckart and Rüppel, in Venezuela. Zoological Studies, 44, 157-190.

Banner, D.M. \& Banner, A.H. (1982) The alpheid shrimp of Australia, part III: the remaining alpheids, principally the genus Alpheus, and the family Ogyrididae. Records of the Australian Museum, 34, 1-357.

Bruce, A.J. (1994) Alpheus fenneri, sp. nov. and A. williamsi, sp. nov., two new Indo-West Pacific alpheid shrimps of the brevirostris species group. The Beagle, 11, 15-28.

Chace, F.A. Jr. (1972) The shrimps of the Smithsonian-Bredin Caribbean expeditions with a summary of the West Indian shallow-water species (Crustacea: Decapoda: Natantia). Smithsonian Contributions to Zoology, 98, i-x + 1-179.

Chace F.A. Jr. (1988) The caridean shrimps (Crustacea: Decapoda) of the Albatross Philippine Expedition, 1907-1910, part 5: family Alpheidae. Smithsonian Contributions to Zoology, 466, i-v + 1-99.

Chen, Y. \& Yeh, C.C. (1958) Notes on some Gephyrea of China with descriptions of four new species. Acta Zoologica Sinica, 10, 265-278.

Christoffersen, M.L. (1998) Malacostraca. Eucarida. Caridea, Crangonoidea and Alpheoidea (except Glyphocrangonidae and Crangonidae). In: Young P.S. (ed.), Catalogue of Crustacea of Brazil, pp. 351-372. Museu Nacional, Rio de Jan- 
eiro.

Coelho Filho, P.A. (2006) Checklist of the decapods (Crustacea) from the outer continental shelf and seamounts from northeast of Brazil - REVIZEE Program (NE III). Zootaxa, 1184, 1-27.

Fisher, W.K. (1946) Echiuroid worms of the North Pacific Ocean. Proceedings of the United States National Museum, 96, 215-292.

Folmer, O., Black, M., Hoeh, W., Lutz, R. \& Vrijenhoek, R. (1994) DNA primers for amplification of mitochondrial cytochrome $c$ oxidase subunit I from diverse metazoan invertebrates. Molecular Marine Biology and Biotechnology, 3, 294-299.

Kim, W. \& Abele, L.G. (1988) The snapping shrimp genus Alpheus from the eastern Pacific (Decapoda: Caridea: Alpheidae). Smithsonian Contributions to Zoology, 454, 1-119.

Knowlton, N. \& Mills, D.K. (1992) The systematic importance of color and color pattern: evidence for complexes of sibling species of snapping shrimp (Caridea: Alpheidae: Alpheus) from the Caribbean and Pacific coasts of Panama. Proceedings of the San Diego Society of Natural History, 18, 1-5.

Knowlton, N. \& Weigt, L.A. (1997) Species of marine invertebrates: a comparison of the biological and phylogenetic species concepts. In Claridge, M. F., Dawah, H. A. \& Wilson, M. R. (eds.), Species: the units of biodiversity. Systematics Association (UK) Special Volume Series 54, pp. 199-219. Chapman and Hall, London.

Knowlton, N. \& Weigt, L.A. (1998) New dates and new rates for divergence across the Isthmus of Panama. Proceedings of the Royal Society of London, Biological Sciences, 265, 2257-2263.

Knowlton, N., Weigt, L.A., Solorzano, L.A., Mills, D.K. \& Bermingham, E. (1993) Divergence in proteins, mitochondrial DNA, and reproductive compatibility across the Isthmus of Panama. Science, 260, 1629-1632.

Nomura, K. (2000) Host and color variation of Alpheus barbatus Coutière (Crustacea, Alpheidae) in Japan. Biological Magazine of Okinawa, 38, 59-64.

Ramos, G (1995) Nuevos registros de camarones alfeídos (Crustacea, Decapoda, Alpheidae) para el Pacífico de Colombia. In: Cantera, J.R. \& Restrepo, J.D. (eds.), Delta del Río San Juan, Bahías de Málaga y Buenaventura, Pacífico Colombiano. Tomo II, pp. 127-153. Colciencias, Univeridad EAFIT y Universidad del Valle, Colombia.

Schmitt, W.L. (1926) The macruran, anomuran, and stomatopod crustaceans collected by the American Museum Congo Expedition, 1909-1915. With field notes by Herbert Lang and James P. Chapin. Bulletin of the American Museum of Natural History, 53, 1-67, pls. 1-9.

Silliman, B.R., Layman, C.A. \& Altieri, A.H. (2003) Symbiosis between an alpheid shrimp and a xanthoid crab in saltmarshes of Mid-Atlantic States, U.S.A. Journal of Crustacean Biology, 23, 876-879.

Stephen, A.C. \& Edmonds, S.J. (1972) The Phyla Sipuncula and Echiura. Trustees of the British Museum of Natural History, London, $588 \mathrm{pp}$.

Tzeng, M.S. \& Chen, Y.S. (1992) Guide to the seashore life in the East Coast National Scenic Area of Taiwan. Taiwan, $221 \mathrm{pp}$.

Vargas, R. \& Cortés, J. (1999) Biodiversidad marina de Costa Rica: Crustacea: Decapoda (Penaeoidea, Sergestoidea, Stenopodidea, Caridea, Thalassinidea, Palinura) del Caribe. Revista de Biología Tropical, 47, 887-911.

Wicksten, M.K. \& Hendrickx, M.E. (1992) Checklist of penaeoid and caridean shrimps (Decapoda: Penaeoidea, Caridea) from the eastern tropical Pacific. Proceedings of San Diego Society of Natural History, 9, 1-11.

Wicksten, M.K. \& Hendrickx, M.E. (2003) An updated checklist of benthic marine and brackish water shrimps (Decapoda: Penaeoidea, Stenopodidea, Caridea) from the eastern tropical Pacific. In: Hendrickx, M. (ed.), Contribuciónes al estudio de los crustáceos del Pacifico Este, Instituto de Ciencias del Mar y Limnología, Universidad Nacional Autónoma de México, México, pp. 49-76.

Williams, S.T. \& Knowlton, N. (2001) Mitochondrial pseudogenes are pervasive and often insidious in the snapping shrimp genus Alpheus. Molecular Biology and Evolution, 18, 1484-1493.

Williams, S.T., Knowlton, N., Weigt, L.A. \& Jara, J.A. (2001) Evidence for three major clades within the snapping shrimp genus Alpheus inferred from nuclear and mitochondrial gene sequence data. Molecular Phylogenetics and Evolution, 20, 375-389. 
